\title{
Kebijakan Refocusing Anggaran Belanja Daerah dalam Penanganan Pandemi COVID-19
}

\section{Refocusing Policy on Regional Budgets in Handling the COVID-19 Pandemic}

\author{
Muhammad Junaidi' ${ }^{1}$, Kadi Sukarna² ${ }^{2}$ Zainal Arifin ${ }^{3}$, Soegianto ${ }^{4}$ \\ 1. Universitas Semarang, Indonesia. E-mail: institut.junaidi@gmail.com \\ 2. Universitas Semarang, Indonesia. E-mail: diahmuladi@gmail.com \\ 3. Universitas Semarang, Indonesia.E-mail: zaenal@usm.ac.id \\ 4. Universitas Semarang, Indonesia. E-mail: notarissoegianto@gmail.com
}

\begin{tabular}{l}
\hline ARTICLE INFO \\
\hline Keywords: \\
Policy; \\
Refocusing; \\
Regional Spending \\
\\
\end{tabular}

\section{INFO ARTIKEL}

Kata kunci:
Kebijakan;
Refocusing;
Belanja Daerah

\begin{abstract}
Through a normative study approach, it was found that the regional government argued for a budget refocusing policy based on the provisions in the Presidential Instruction on Activity Refocusing, Budget Reallocation, and Procurement of Goods and Services in the Context of Accelerating COVID-19 Handling. Such an arrangement must be too strong a mistake will occur deliberately (malicious intent) for the policy that regulates the actual policy. What should be regulated in the budget refocus policy policy is the issuance of a Government Regulation in Lieu of a Law which forms the basis of the Law on Regional Government which has been the basis for the legality of the regional financial policy process as well as other regulations.
\end{abstract}

\section{Pendahuluan}

Pasca ditetapkannya COVID-19 sebagai pandemi nasional, secara otomatis kebijakan pemerintah telah dilakukan penyesuaian. Hal ini tentunya tidak terkecuali pada masalah 
pokok yang berkaitan dengan penyelesaian keuangan yang dijalankan baik oleh pemerintah pusat dan pemerintah daerah.

Pemerintah pusat sendiri setidak-tidaknya telah menyiapkan regulasi terkait penyesuaian penganggaran dalam kerangka penanganan COVID-19 tersebut di antaranya terdapat dalam beberapa regulasi di antaranya Perppu Nomor 1 tahun 2020 tentang Kebijakan Keuangan Negara dan Stabilitas Sistem Keuangan Untuk Penanganan COVID-19, Keppres Nomor 7 tahun 2020 tentang Gugus Tugas Percepatan Penanganan COVID-19, Perpres Nomor 52 tahun 2020 tentang Pembangunan Fasilitas Observasi dan Penampungan dalam Penanggulangan COVID-19 atau Penyakit Infeksi Emerging di Pulau Galang, Kota Batam, Provinsi Kepulauan Riau, Instruksi Presiden Nomor 4 tahun 2020 tentang Refocusing Kegiatan, Realokasi Anggaran, serta Pengadaan Barang dan Jasa Dalam Rangka Percepatan Penanganan COVID-19, PP Nomor 21 tahun 2020 tentang Pembatasan Sosial Berskala Besar Dalam Rangka Percepatan Penanganan COVID-19 dan Keppres Nomor 11 tahun 2020 tentang Penetapan Status Kedaruratan Kesehatan Masyarakat.

Jika kita telaah dari sisi penyusunan peraturan, beberapa produk terlahir karena sifat kegentingan memaksa yang bukan hanya dilihat dari indikator terbitnya Perppu, akan tetapi juga peraturan selain Perppu. Istilah kegentingan memaksa tentunya juga sangat berkaitan dengan kedaruratan. Dalam terminologi kedaruratan, aspek kepentingan masyarakat menjadi salah satu indikator sejauh mana nilai-nilai dalam kedaruratan tersebut layak atau tidak untuk diterapkan.

Dari segi bentuk dan jenis ancaman yang ditimbulkan oleh kejadian dalam keadaan darurat itu, ada yang berbentuk ancaman terhadap selamatan penduduk, ada yang mengancam integritas wilayah negara, ada pula yang mengancam prinsip-prinsip bernegara serta kualitas penyelenggaraan demokrasi dan atau keadilan. Misalnya, ancaman perang saudara atau bencana alam seperti letusan Gunung Merapi di Jawa Tengah pada 2006 jelas mengancam keselamatan penduduk. Agresi oleh pasukan Kerajaan Belanda yang ingin kembali menjajah Indonesia setelah Perang Dunia Ke-Il jelas mengancam integritas wilayah Republik Indonesia. Akan tetapi, ancaman terhadap kualitas proses penyelenggaraan pemilihan umum sesuai peraturan perundangundangan, seperti yang terjadi pada proses persiapan Pemilu 2004 timbul kejadian yang menyebabkan tahap-tahap pekerjaan administratifnya harus diubah agar tidak melanggar undang-undang. Sebagai jalan keluarnya, keadaan demikian dianggap sebagai kegentingan yang memaksa sebagaimana dimaksud dalam Pasal 22 Ayat (1) UUD 1945 yang menyebabkan Presiden menetapkan peraturan pemerintah sebagai pengganti undang-undang1.

Sebagai pelajaran terpenting dari itu semua, tentunya dalam hal ini pemerintah harus menyediakan instrumen yang secara tepat dan strategis dalam upaya melakukan perlindungan terhadap segenap tumpah darah rakyat Indonesia yang sifatnya penting dan mendesak untuk dilakukan secara objektif. Di negara-negara seperti Indonesia, potensi

1 Jimly Asshidiqie, Hukum Tata Negara Darurat (Jakarta: RajaGrafindo Persada, 2007), 31. 
kerawanan banyak sekali, baik yang disebabkan oleh gejala alam ataupun yang timbul karena ulah manusia sendiri. Masyarakat Indonesia sangat majemuk, baik dan segi anutan agama, etnisitas, dan tradisi budaya, maupun dan segi disparitas tingkat pendidikan dan kesejahteraan pada umumnya. Jumlah penduduk Indonesia juga sangat besar, yaitu sebagai negara dengan jumlah penduduk terbanyak keempat di dunia setelah Cina, India, dan Amerika Serikat. Wilayah Indonesia juga sangat luas yang terdiri atas 17.000-an pulau hingga wilayah perairan Indonesia mencakup lebih dan dua per tiga seluruh wilayah Indonesia. Dalam kondisi yang semacam itu, tingkat kerawanan yang ada sangatlah kompleks dan banyak sekali kemungkinan terjadi dalam segala bentuk manifestasinya ${ }^{2}$.

Hal inilah yang salah satunya telah dibuktikan melalui kejadian COVID-19. Kebijakan pemerintah saat ini tentunya harus menyediakan yang hal-hal yang sifatnya objektif dan cepat sehingga masalah pokok penanganan dan percepatan penyusunan kebijakan dalam mengatasi pandemi COVID-19 dengan sedemikian rupa dapat ditangani secara baik dan tepat. Yosephus ${ }^{3}$ dalam pendapatnya kebijakan refocusing sangatlah berpotensi terhadap tindak pidana pada saat bencana alam terjadi. Adanya pengalokasian dana dari pemerintah untuk penanggulangan bencana rawan disalahgunakan oleh oknum tertentu yang seharusnya memiliki kewajiban untuk mengelola dana penanggulangan bencana tersebut dengan memperhatikan bahwa dana tersebut diperuntukkan bagi kepentingan kemanusiaan.

Di sinilah hal yang patut dilakukan kajian yang mendalam adalah sejauh mana sinergi pemahaman kebijakan Refocusing anggaran jika kita melakukan fokus kajian yang dilakukan oleh belanja daerah dalam penanganan pandemi COVID-19. Tentunya hal ini menjadi sangat menarik mengingat di Indonesia sendiri upaya mendelegasikan penanganan COVID-19 oleh pemerintah pusat banyak di delegasikan melalui kewenangan yang diberikan kepada pemerintah daerah.

\section{Metode}

Metodologi pendekatan yang digunakan dalam kajian ini adalah social legal research. Kajian socio legal research merupakan kajian yang "memadukan" kajian hukum doktrinal dengan kajian sosial. Perpaduan ini dilandasi oleh keyakinan bahwa aturan hukum tidak pernah bekerja di ruang hampa. Aturan hukum bekerja di ruang yang penuh dengan sistem nilai, kepentingan yang dapat dominan, tidak netral. Oleh karena itu di dalam kajian socio legal research dilakukan studi tekstual terhadap Pasal-Pasal dalam peraturan hukum. Selanjutnya dilakukan analisis secara tajam apakah aturan-aturan itu di dalam masyarakat dapat mewujudkan keadilan, kestabilan hidup dan kesejahteraan di dalam masyarakat. Untuk itulah dilakukan penelitian sosial yang untuk akurasi dan pencapaian kebenarannya didasarkan pada paradigma. Penelitian sosial itu lalu bisa disimpulkan

\footnotetext{
Ibid., 33.
}

Yosephus Ary Sepdiandoko, "Penanganan Tindak Pidana Korupsi Penyalahgunaan Dana Penanggulangan Bencana sebagai Upaya Penegakan Hak Masyarakat Ditinjau dari Hak Ekonomi Sosial dan Budaya," Lex Administratum V, no. 5 (2017): 97. 
aturan-aturan hukum itu dapat memberikan keadilan atau tidak ${ }^{4}$. Sumber data penelitian terdiri dari sumber data primer dan sumber data sekunder, sumber data primer dan sekunder peneliti uraikan sebagai berikut: Sumber data primer yaitu data yang diperoleh langsung melalui sumber di lapangan penelitian. Sumber data primer memungkinkan peneliti menemukan data/hasil penelitian secara otentik dari sumber yang dipercaya. Sedangkan Sumber data sekunder yaitu sumber data yang meliputi bahan hukum primer, bahan hukum sekunder dan bahan hukum tertier yang ke semuanya dapat ditemukan melalui peraturan perundang-undangan, buku-buku, tulis-tulisan, koran, majalah dan sumber data tertulis lainnya yang diperoleh dari hasil studi pustaka, studi dokumentasi dan studi arsip. Bahan hukum primer yaitu bahan-bahan hukum yang mengikat. Bahan hukum sekunder terdiri dari rancangan peraturan perundang-undangan, Hasil karya ilmiah para pakar, baik yang telah diterbitkan atau yang belum atau tidak diterbitkan tetapi terdokumentasi dalam lembaga perpustakaan tertentu, hasil penelitian, baik yang telah dipublikasikan maupun yang belum dan hasil seminar dan diskusi. Sedangkan Bahan hukum tertier dalam hal ini terdiri dari ensiklopedi, Kamus-kamus hukum dan kamus umum, Bibliografi. Metode ini di gunakan untuk mendapatkan data berupa dokumen yaitu arsip-arsip yang dibutuhkan untuk penelitian ini. Sedangkan analisa dilakukan dengan analisa kualitatif. Dalam analisa kualitatif, peneliti lebih menekankan adanya analisa data sekunder dan primer secara terstruktur. Analisis secara kualitatif dalam hal ini adalah upaya yang dilakukan dengan jalan bekerja dengan data, mengorganisasikan data, memilah-milahnya menjadi satuan yang dapat dikelola, menyintesiskannya, mencari dan menemukan pola, menemukan apa yang penting dan apa yang dipelajari, dan memutuskan apa yang dapat diceritakan kepada orang lain ${ }^{5}$. Analisis secara kualitatif diharapkan menemukan hasil kajian secara komprehensif.

\section{Teori-teori Terkait dalam Refocusing Anggaran Belanja Daerah dalam Menghadapi COVID-19}

\subsection{Teori Implementasi}

Frasa implementasi menjadi salah satu materi pokok dalam kajian hukum dan perundangundangan sebagai indikator mengukur sejauh mana hukum dapat berlaku. Implementasi atau dengan kata kerja diimplementasikan dalam Undang-Undang Nomor 12 tahun 2011 tentang Pembentukan Peraturan Perundang-undangan ditegaskan dalam asas dimana setiap peraturan perundang-undangan harus dapat diterapkan.

Pengertian Implementasi menurut kadir adalah kegiatan yang dilakukan untuk menguji data dan menerapkan sistem yang diperoleh dari kegiatan seleksi. Jadi dapat disimpulkan bahwa implementasi merupakan proses untuk menguji antara konsep dengan konseptual atau antara teks dan konteks. Berangkat dari sini implementasi dapat dimaksudkan suatu

4 FX Adji Samekto, "Menempatkan Paradigma Penelitian dalam Pendekatan Hukum Non-Doktrinal dan Penelitian dalam Ranah Sosio-Legal," Pedoman Bagi Mahasiswa S3 Ilmu Hukum UNDIP.

5 Lexi J. Moleong, Metode Penelitian Kualitatif (Bandung: Remaja Rosdakarya, 2009), 248. 
mekanisme dalam menjalankan pengujian atas konsep yang telah ada sebelumnya, peruntukannya untuk sebuah tujuan tertentu. Tentunya implementasi membutuhkan variabel-variabel pencapaian yang ingin diharapkan. Implementasi dalam arti tersebut sebagaimana perbandingan penelitian sebelumnya yang dilakukan oleh Bayu Dwi Anggono $^{6}$ dimana terdapat disharmonisasi dalam peraturan penanggulangan bencana selama ini yang dapat dilihat dalam perspektif bencana.

\subsection{Teori Refocusing}

Weston dkk. juga berpendapat bahwa refocusing akan memudahkan manajer untuk memantau dan membuat keputusan yang lebih baik ketika bisnis perusahaan diposisikan lebih sempit ${ }^{7}$. Hal ini juga terjadi dalam sebuah Negara, konsep Refocusing juga selayaknya diterapkan dalam menjamin stabilitas keuangan sebuah Negara utamanya ketika menghadapi suatu krisis.

Refocusing menjadi salah satu alternatif untuk meminimalisasi terjadinya resesi ekonomi dalam menjamin stabilitas ekonomi nasional. Pertimbangan refocusing tentunya terjadinya hentakan ekonomi global akibat suatu kejadian atau rapuhnya sistem ekonomi akibat dampak dari kebijakan yang tidak tepat atau strategis.

\subsection{Teori Penganggaran Daerah}

Dalam Peraturan Pemerintah Republik Indonesia Nomor 12 Tahun 2019 Tentang Pengelolaan Keuangan Daerah dinyatakan bahwa yang dimaksud dengan Keuangan Daerah adalah semua hak dan kewajiban Daerah dalam rangka penyelenggaraan Pemerintahan Daerah yang dapat dinilai dengan uang serta segala bentuk kekayaan yang dapat dijadikan milik Daerah berhubung dengan hak dan kewajiban Daerah tersebut. Sedangkan yang dimaksud dengan Pengelolaan Keuangan Daerah adalah keseluruhan kegiatan yang meliputi perencanaan, penganggaran, pelaksanaan, penatausahaan, pelaporan, pertanggungjawaban, dan pengawasan Keuangan Daerah.

Menurut Pekei dalam Dealice Ivana Barbakem ${ }^{8}$, anggaran pemerintah atau yang disebut dengan Anggaran Pendapatan dan Belanja Negara (APBN) dan Anggaran Pendapatan dan Belanja Daerah (APBD) yang dikelola oleh pemerintah, maka anggaran adalah pernyataan tentang estimasi kinerja yang akan dicapai selama periode tertentu yang dinyatakan dalam ukuran finansial atau uang. Dalam proses penyusunan anggaran disebut penganggaran, maka penganggaran disusun harus berdasarkan kepada kepentingan organisasi sektor publik, dalam penyusunan anggaran oleh pemerintah merupakan tahap yang cukup luas karena tidak hanya mempertimbangkan ekonomi tetapi juga terhadap

6 Bayu Dwi Anggono, "Harmonisasi Peraturan Perundang-undangan di Bidang Penanggulangan Bencana," Mimbar Hukum 22, no. 2 (2010): 373-390.

7 Fauzias Mat Nor, Norazlao Alias, dan Mohd Hasimi Yaacob, "Corporate Restructuring: Firm Characteristics and Performance," Jurnal Pengurusan 27 (2008): 129-141.

8 Dealice Ivana Barbakem, Jantje J. Tinangon, dan Harijanto Sabijono, "Analisis Perencanaan dan Penganggaran Untuk Anggaran Pendapatan dan Belanja Daerah pada Badan Keuangan Kabupaten Kepulauan Sangihe Tahun Anggaran 2015," Jurnal Riset Akuntansi Going Concern 13, no. 1 (2018): 3. 
faktor sosial politik yang semakin kental dalam organisasi masyarakat. Penganggaran pada pemerintah terkait dengan penentuan jumlah alokasi dana untuk tiap-tiap program atau aktivitas yang akan dilakukan dalam satu moneter, untuk itu ada beberapa aspek yang harus dipenuhi dalam penyusunan anggaran pemerintah adalah aspek perencanaan, aspek pengendalian, serta aspek transparansi dan akuntabilitas secara umum. Dalam penyusunan anggaran pemerintah mempunyai beberapa prinsip anggaran pemerintah di antaranya penguasaan otoritas oleh legislatif, adalah anggaran harus mendapatkan persetujuan terlebih dahulu oleh legislatif sebelum anggaran tersebut dibelanjakan oleh pemerintah/eksekutif dan bersifat transparan dan terbuka yang anggaran disusun secara terbuka atau transparan serta dapat diketahui dengan mudah oleh masyarakat umum.

\section{Regulasi Mengatur Refocusing}

Jika ditelaah dari aspek kebijakan penganggaran, maka setiap regulasi yang disusun pemerintah tentunya berbasiskan anggaran. Hal ini tidak terlepas dari substansi bahwa terdapat pengaturan yang khusus terkait Refocusing anggaran yang dibuat pemerintah yaitu Instruksi Presiden Nomor 4 tahun 2020 tentang Refocusing Kegiatan, Realokasi Anggaran, serta Pengadaan Barang dan Jasa Dalam Rangka Percepatan Penanganan COVID-19, akan tetapi setiap regulasi yang dibuat pemerintah tentunya semuanya berbasiskan kebutuhan anggaran.

Dalam Inpres Nomor 4 tahun 2020 tentang Refocusing Kegiatan, Realokasi Anggaran, serta Pengadaan Barang dan Jasa Dalam Rangka Percepatan Penanganan COVID-19 sendiri, fokus pengaturan lebih menitiktekankan upaya realokasi anggaran yang sebelumnya diperuntukkan untuk selain penanganan COVID-19 yang kemudian diubah fokus pada upaya mempercepat penanganan COVID-19. Hal ini menjadi sangatlah penting mengingat COVID-19 menjadi salah satu kejadian yang sangat luar biasa. Maka secara substansi jika kita meninjau dari konsep kepentingan masyarakat Refocusing anggaran menjadi suatu hal yang keharusan.

Presiden Republik Indonesia, Joko Widodo, menekankan penerbitan Inpres No.4/2020, yang menginstruksikan, seluruh Menteri/Pimpinan/Gubernur/Bupati/Walikota mempercepat refocusing kegiatan, realokasi anggaran dan pengadaan barang jasa penanganan COVID-19 Instruksi Presiden Nomor 4 tahun 2020 tentang refocusing kegiatan, realokasi anggaran, serta pengadaan barang dan jasa dalam rangka percepatan penanganan COVID-19 Pemerintah harus menentukan skala prioritas dengan mengurutkan anggaran belanja berdasarkan tingkat urgensinya. Pemerintah dapat melakukan refocusing pada anggaran terutama untuk bidang kesehatan dan sosial. Refocusing anggaran belanja ini juga diperlukan karena merosotnya asumsi anggaran pendapatan. Dalam memudahkan perencanaan kegiatan, koordinasi pelaksanaan, serta monitoring dan evaluasi kinerja penanganan pandemi COVID-19, alokasi dana penanganan pandemi dikelompokkan dalam klasifikasi akun khusus COVID-19 Pemerintah dapat juga melakukan pemangkasan pada belanja-belanja tertentu misalnya pengeluaran untuk perjalanan dinas, belanja rapat, bimbingan teknis, penyuluhan, dan 
sejenisnya untuk dialihkan pada penanganan COVID-19 yaitu biaya perjalanan dinas, biaya belanja modal 9 .

Dalam perspektif kita menyusun peraturan jika kita meninjau Undang-Undang Nomor 12 tahun 2011 tentang Pembentukan Peraturan Perundang-undangan, terdapat beberapa asas pokok. Pasal 5 Undang-Undang No. 12 Tahun 2011 tentang Pembentukan Peraturan Perundang-undangan wajib mendasarkan pada: a. Kejelasan tujuan b. Kelembagaan atau pejabat pembentuk yang tepat c. Kesesuaian antara jenis, hierarki dan materi muatan d. Dapat dilaksanakan e. Kedayagunaan dan kehasilgunaan f. Kejelasan rumusan g. Keterbukaan Di samping asas-asas tersebut dalam Pasal 5, asas lainnya yang juga harus terkandung pada peraturan perundang-undangan sebagaimana diatur dalam UndangUndang No. 12 Tahun 2011 tentang Pembentukan Peraturan Perundang-undangan adalah: a. Pengayoman b. Kemanusiaan c. Kebangsaan d. Kekeluargaan e. Kenusantaraan f. Bhinneka Tunggal Ika g. Keadilan h. Kesamaan kedudukan dalam hukum dan pemerintahan i. Ketertiban dan Kepastian hukum, dan j. Keseimbangan, Keserasian dan keselarasan.

Jika kita meninjau dari ketentuan Refocusing anggaran di antaranya dalam Inpres Nomor 4 tahun 2020 tentang Refocusing Kegiatan, Realokasi Anggaran, serta Pengadaan Barang dan Jasa Dalam Rangka Percepatan Penanganan COVID-19, upaya menyusu sumber hukum ketentuan tersebut disandarkan pada asas dapat dilaksanakan, kedayagunaan dan kehasilgunaan. Jaminan kepentingan dari asas tersebut tentunya mengarah jaminan atas kepentingan masyarakat.

Indikator adanya asas tersebut pemaknaan dari sisi regulasi bahwa Refocusing anggaran merupakan bentuk regulasi yang keluar dari ranah keadilan formal, dimana dalam keadilan formal sendiri nilai prosedural peraturan yang sudah tertanam harus memang benar-benar diterapkan sedemikian rupa. Jika keadilan formal diterapkan maka Refocusing anggaran tidak dapat diterapkan karena penganggaran dalam APBN maupun APBD terkait pengadaan barang dan jasa utamanya telah menjadi kesepakatan untuk kepentingan tertentu.

Akan tetapi dalam arti nilai-nilai yang terdapat dalam ketentuan Refocusing anggaran, substansi keadilan materiil menjadi salah satu objek yang dikedepankan. Lebih lanjut Mahfud menyatakan, sejak perubahan tahap ketiga UUD 1945, konstitusi kita sudah mengarahkan agar penegakan hukum di Indonesia secara prinsip menganut secara seimbang segi-segi baik dan konsepsi rechtsstaat dan the rule of law sekaligus yakni menjamin kepastian hukum dan menegakkan keadilan substansial ${ }^{10}$.

Di samping itu, juga dapat dimaknai sebagai wujud keadilan sosial yang menitik tekankan beberapa aspek nilai yang terakomodasi dalam konsep keadilan. Masalah pokok keadilan

9 Dina Eva Silalahi dan Rasinta Ria Ginting, "Strategi Kebijakan Fiskal Pemerintah Indonesia Untuk Mengatur Penerimaan dan Pengeluaran Negara Dalam Menghadapi Pandemi Covid-19," Jesya (Jurnal Ekonomi \& Ekonomi Syariah) 3, no. 2 (2020): 165.

10 Ni'matul Huda, Hukum Tata Negara Indonesia (Jakarta: RajaGrafindo Persada, 2015), 206-207. 
sosial adalah pembagian (distribusi) nikmat dan beban dalam masyarakat yang oleh Brian Barry dirangkum dalam tiga kelompok yaitu: (1) ekonomi (uang); (2) politik (kuasa); dan sosial (status) ${ }^{11}$.

Maka dalam arti regulasi, Refocusing anggaran menjadi salah satu kebijakan yang memang dapat diterima bukan hanya dari sisi pembentukan peraturan perundang-undangan, akan tetapi sisi konstitusionalitas dimana aspek konstitusionalitas lebih pada upaya menyandarkan kepentingan masyarakat sebagai identitas norma tertinggi dalam konsep hukum di Indonesia.

\section{Dampak dari Refocusing}

Segala bentuk kebijakan tentunya menimbulkan dampak atau konsekuensi yang harus dihadapi. Hal ini tidak terlepas dari kebijakan Refocusing anggaran. Refocusing anggaran menimbulkan berbagai macam perspektif dampak yang ditimbulkan di antaranya adalah penganggaran sebelumnya tentunya tidak dapat dijalankan sebagaimana mestinya.

Kebijakan penganggaran dengan menggunakan pendekatan Refocusing anggaran dalam penanganan COVID-19 pada pemerintahan daerah tentunya harus menggunakan pendekatan kehati-hatian. Hal ini melihat dari konsekuensi terbengkalainya penganggaran sebelumnya yang pastinya terabaikan dengan adanya penganggaran yang baru. dampak yang jelas-jelas terbukti adalah dengan adanya terbengkalainya kebijakan yang dijalankan sebelumnya dalam penyelenggaraan pemerintahan.

Adanya refocusing anggaran memang di satu sisi telah menggambarkan sejauh mana arahan pemerintah pusat kepada pemerintah daerah untuk dapat mengelola keuangan daerah di tengah COVID-19. Hal ini berlandaskan bahwa, regional autonomy is no longer just carrying out instructions from the center, but regions are really expected to have the freedom to increase creativity in developing the potential that during the era of autonomy can be said to be isolated ${ }^{12}$. Oleh karenanya jika refocusing anggaran tidak dijalankan sejalan dengan kebijakan penganggaran yang tepat, maka memungkinkan terjadinya instabilitas penganggaran dalam keuangan daerah. The acceleration and optimization of budget absorption can be done through good budget planning and budget execution conducted appropriately and in accordance with schedule so that the implementation of programs and activities can reach the target in order to improve the performance of the institution $^{13}$.

11 Husnan Wadi, "Perselisihan Keadilan, Kemanfaatan, dan Kepastian Hukum dalam Privatisasi Sumber Daya Air," Jurnal IUS II, no. 5 (2014): 225.

12 Mardiasmo dalam Arifin dan Gagaring Pagalung, "Empirical Study of the Effect of Participation of Budget in Managerial Performance," International Journal of Advanced Engineering, Management and Science 4, no. 9 (2018): 645.

13 Heriberta Heriberta, Aulia Tasman, dan Yanilia Yanilia, "Analysis of Budget Spending and its Affect on Jambi Government Performance," Jurnal Perspektif Pembiayaan dan Pembangunan Daerah 5, no. 4 (2018): 254. 


\section{Pelanggaran Hukum Refocusing}

Penyalahgunaan wewenang menurut penulis adalah suatu perbuatan melawan hukum yang paling berpotensi dilakukan oleh PA/KPA dalam Pengadaan Barang dan Jasa Pemerintah, Karena PA/KPA adalah jabatan, dan di dalam jabatan adanya kewenangan, tanpa adanya kewenangan tidak mungkin adanya jabatan, hal inilah yang menjadi alasan PA/KPA sangat berpotensi melakukan penyalahgunaan wewenang. Dengan adanya wewenang pada diri PA/KPA potensi terjadi penyalahgunaan wewenang sangat besar, ketidakhati-hatian, ketidakcermatan Pengguna Anggaran/Kuasa Pengguna Anggaran (PA/ KPA) bisa membuat dirinya terjebak dalam Perbuatan melawan hukum yang berbentuk penyalahgunaan wewenang, karena penyalahgunaan wewenang merupakan perbuatan melawan hukum yang lebih rentan dilakukan oleh pejabat, dikarenakan pejabat memiliki wewenang ${ }^{14}$.

Pandangan dalam jurnal tersebut mengisyaratkan bahwa adanya pelanggaran Refocusing mengingat telah terjadi penyalahgunaan wewenang dalam proses pengambilan kebijakan. Penyalahgunaan wewenang terjadinya karena indikator adanya Dalam hukum pidana konsep liability atau pertanggungjawaban. Pertanggungjawaban itu merupakan konsep sentral yang dikenal dengan ajaran kesalahan. Dalam bahasa latin ajaran kesalahan ini dikenal dengan sebutan mens rea. Suatu perbuatan tidak mengakibatkan seorang bersalah kecuali jika pikiran orang itu jahat. Doktrin mens rea itu dilandaskan pada maxim actus nonfacit reum nisi mens sit rea, yang berarti "suatu perbuatan tidak mengakibatkan seseorang bersalah kecuali jika pikiran orang itu jahat"15. Salah satu penyimbangan yang nyata terkait Refocusing anggaran adalah adanya fokus pelaksanaan dan pengalokasian anggaran ada pada tangan eksekutif. Dalam sebuah pandangan dijurnal Yudisial, hal ini dapat dijelaskan bahwa terdapat hubungan adequate antara usulan anggota Dewan perihal penganggaran yang menyimpang dengan pengesahan anggaran tersebut oleh kepala daerah yang mengakibatkan keluarnya Perda yang menyimpang dari ketentuan. Dalam rangkaian peristiwa tersebut terdapat dua pihak yang terlibat yaitu pihak legislatif sebagai pengusul dan pihak eksekutif sebagai pengesah anggaran dimana masing-masing perbuatan tersebut tidak bisa dipandang berdiri sendiri yang terlepas hubungannya satu dengan lainnya, melainkan perbuatan peserta dilihat dalam hubungan dan sebagai kesatuan dengan peserta lainnya. Jadi terdapat suatu kesatuan rangkaian peristiwa yang saling berhubungan sehingga melahirkan delik ${ }^{16}$.

Jadi adanya Refocusing anggaran tersebut yang berpotensi hanya didasarkan pada instruksi presiden akan menjadikan penganggaran berbasiskan otonomi daerah diabaikan. Pengabaiannya adalah prinsip penganggaran yang harusnya dijalankan oleh

14 M. Sofian Assaori, "Pertanggungjawaban Pidana Pejabat Pengguna Anggaran/Kuasa Pengguna Anggaran (PA/KPA) dalam Pengadaan Barang dan Jasa Pemerintah," Kajian Hukum dan Keadilan III, no. 9 (2015): 590.

15 Ibid., 591.

16 Saryono Hanadi, M.I. Wiwik Yuni Hastuti, dan Alef Musyahadah Rahmah, "Tindak Pidana Korupsi dalam Penyusunan APBD (Kajian Pustaka Nomor 76/PID.B/2008/PN.PWT),” Jurnal Yudisial III, no. 1 (2010): 28-29. 
organ eksekutif dan legislatif daerah terarah pada organ eksekutif saja, baik dari proses pengalihan sampai dengan penggunaan anggaran. Potensi inilah yang disebut dalam paragraf sebelumnya dikenal dengan adanya delik.

\section{Rekomendasi Kebijakan Alternatif}

Menurut Undang-Undang Nomor 23 tahun 2014 tentang Pemerintahan daerah dinyatakan bahwa: Perencanaan dan penganggaran daerah merupakan cermin dari efektivitas pengelolaan keuangan daerah yang baik untuk menunjang keberhasilan desentralisasi fiskal. Proses perencanaan dimulai dari Rencana Pembangunan Jangka Panjang Daerah (RPJPD) dengan memperhatikan Rencana Pembangunan Jangka Menengah Nasional. RPJPD merupakan suatu dokumen perencanaan pembangunan daerah untuk periode 20 (dua puluh) tahun yang digunakan sebagai acuan dalam penyusunan Rencana Pembangunan Jangka Menengah Daerah (RPJMD) untuk setiap jangka waktu 5 (lima) tahun. Setelah RPJMD ditetapkan, pemerintah daerah menyusun Rencana Kerja Pemerintah Daerah (RKPD) yang merupakan penjabaran dari RPJMD untuk jangka waktu 1 (satu) tahun yang mengacu kepada Rencana Kerja Pemerintah. Kepala daerah berdasarkan RKPD menyusun rancangan kebijakan umum APBD. Rancangan kebijakan Umum APBD yang telah dibahas kepala daerah bersama DPRD, selanjutnya disepakati menjadi Kebijakan Umum APBD (KUA). Berdasarkan kebijakan umum APBD yang telah disepakati, pemerintah daerah dan DPRD membahas rancangan prioritas dan plafon anggaran sementara (PPAS) yang disampaikan oleh kepala daerah. Kemudian Kepala daerah menerbitkan pedoman penyusunan Rencana Kerja dan Anggaran (RKA) SKPD sebagai pedoman kepala SKPD menyusun RKA-SKPD berdasarkan nota kesepakatan. Setelah RKA-SKPD dibuat, selanjutnya adalah menyusun rencana peraturan daerah tentang APBD dan rancangan peraturan kepala daerah tentang penjabaran APBD. Rencana peraturan tersebut akan dievaluasi kemudian ditetapkan oleh kepala daerah menjadi peraturan daerah tentang APBD dan peraturan kepala daerah tentang penjabaran APBD ${ }^{17}$.

Jika merujuk pada mekanisme di atas, maka kebijakan dalam yaitu Instruksi Presiden Nomor 4 tahun 2020 tentang Refocusing Kegiatan, Realokasi Anggaran, serta Pengadaan Barang dan Jasa Dalam Rangka Percepatan Penanganan COVID-19, sangatlah bertentangan dengan basis norma yang terdapat dalam Undang-Undang Nomor 23 tahun 2014 tentang Pemerintahan Daerah yang merupakan acuan utama pengaturan dalam sistem penganggaran keuangan daerah. Di sinilah memang penting untuk dibentuknya konsep peraturan pemerintah pengganti undang-undang yang menurut Undang-Undang Nomor 12 tahun 2011 tentang Pembentukan Peraturan Perundang-undangan terdapat kesejajaran norma antara Undang-Undang Nomor 23 tahun 2014 dengan Peraturan Pemerintah Pengganti Undang-Undang (Perppu).

17 Humas DJPK, "Perencanaan dan Penganggaran Keuangan Daerah," Direktorat Jenderal Perimbangan Keuangan Kementerian Keuangan Republik Indonesia, last modified 2017, diakses Juni 14, 2020, http://www.djpk.kemenkeu.go.id/?p=5747. 
Pada sisi lain, sifat pelaksanaan Refocusing anggaran yang formatnya lebih banyak mendelegasikan kewenangan kepada kepala daerah menjadikan prinsip penyelenggaraan pemerintahan daerah yang oleh Undang-Undang Dasar Negara Republik Indonesia pada pasal 18 terabaikan. Idealnya kewenangan antara kepala daerah dan DPRD dalam keuangan daerah harus berjalan beriringan yang nanti diharapkan potensi mensrea (niat jahat) terabaikan.

\section{Penutup}

Kebijakan penganggaran daerah pada saat pandemi COVID-19 tentunya harus berbasiskan pada kebutuhan untuk mempercepat penanganan baik dari aspek kesehatan, ekonomi, politik dan lain sebagainya yang berhubungan dengan kepentingan masyarakat. Hal inilah yang sebenarnya menjadi dasar lahirnya Instruksi Presiden Nomor 4 tahun 2020 tentang Refocusing Kegiatan, Realokasi Anggaran, serta Pengadaan Barang dan Jasa Dalam Rangka Percepatan Penanganan COVID-19. Namun, potensi terjadinya penyimpangan kebijakan keuangan daerah dari adanya Refocusing anggaran tersebut tampak jelas yaitu dengan menempatkan kedudukan kepala daerah atau organ eksekutif dalam masalah penganggaran maupun pelaksanaan anggaran. Padahal dalam UndangUndang Dasar Negara Republik Indonesia yang dimaksud penganggaran daerah harus dirumuskan oleh organ eksekutif dan legislatif. Di sinilah maka sudah seharusnya instruksi presiden terkait Refocusing anggaran daerah bukan berbentuk Instruksi Presiden akan tetapi harus diganti dengan Peraturan pemerintah pengganti UndangUndang yang seyogyanya nantinya sistem penganggaran yang demikian akan menjadikan dasar hukum termasuk derajat pelaksaan penganggaran daerah dijalankan dan memiliki landasan yuridis yang jelas.

\section{Daftar Pustaka}

Anggono, Bayu Dwi. "Harmonisasi Peraturan Perundang-undangan di Bidang Penanggulangan Bencana.” Mimbar Hukum 22, no. 2 (2010): 373-390.

Arifin, dan Gagaring Pagalung. "Empirical Study of the Effect of Participation of Budget in Managerial Performance." International Journal of Advanced Engineering, Management and Science 4, no. 9 (2018): 645-651.

Assaori, M. Sofian. "Pertanggungjawaban Pidana Pejabat Pengguna Anggaran/Kuasa Pengguna Anggaran (PA/KPA) dalam Pengadaan Barang dan Jasa Pemerintah.” Kajian Hukum dan Keadilan III, no. 9 (2015): 586-600.

Asshidiqie, Jimly. Hukum Tata Negara Darurat. Jakarta: RajaGrafindo Persada, 2007.

Barbakem, Dealice Ivana, Jantje J. Tinangon, dan Harijanto Sabijono. “Analisis Perencanaan dan Penganggaran Untuk Anggaran Pendapatan dan Belanja Daerah pada Badan Keuangan Kabupaten Kepulauan Sangihe Tahun Anggaran 2015." Jurnal Riset Akuntansi Going Concern 13, no. 1 (2018): 1-13.

Hanadi, Saryono, M.I. Wiwik Yuni Hastuti, dan Alef Musyahadah Rahmah. "Tindak Pidana Korupsi dalam Penyusunan APBD (Kajian Pustaka Nomor 76/PID.B/2008/PN.PWT).” 
Jurnal Yudisial III, no. 1 (2010): 15-30.

Heriberta, Heriberta, Aulia Tasman, dan Yanilia Yanilia. "Analysis of Budget Spending and its Affect on Jambi Government Performance." Jurnal Perspektif Pembiayaan dan Pembangunan Daerah 5, no. 4 (2018): 244-256.

Huda, Ni'matul. Hukum Tata Negara Indonesia. Jakarta: RajaGrafindo Persada, 2015.

Humas DJPK. "Perencanaan dan Penganggaran Keuangan Daerah." Direktorat Jenderal Perimbangan Keuangan Kementerian Keuangan Republik Indonesia. Last modified 2017. Diakses Juni 14, 2020. http://www.djpk.kemenkeu.go.id/?p=5747.

Moleong, Lexi J. Metode Penelitian Kualitatif. Bandung: Remaja Rosdakarya, 2009.

Nor, Fauzias Mat, Norazlao Alias, dan Mohd Hasimi Yaacob. "Corporate Restructuring: Firm Characteristics and Performance." Jurnal Pengurusan 27 (2008): 129-141.

Samekto, FX Adji. "Menempatkan Paradigma Penelitian dalam Pendekatan Hukum NonDoktrinal dan Penelitian dalam Ranah Sosio-Legal." Pedoman Bagi Mahasiswa S3 Ilmu Hukum UNDIP.

Sepdiandoko, Yosephus Ary. "Penanganan Tindak Pidana Korupsi Penyalahgunaan Dana Penanggulangan Bencana sebagai Upaya Penegakan Hak Masyarakat Ditinjau dari Hak Ekonomi Sosial dan Budaya." Lex Administratum V, no. 5 (2017): 96-106.

Silalahi, Dina Eva, dan Rasinta Ria Ginting. "Strategi Kebijakan Fiskal Pemerintah Indonesia Untuk Mengatur Penerimaan dan Pengeluaran Negara Dalam Menghadapi Pandemi Covid-19." Jesya (Jurnal Ekonomi \& Ekonomi Syariah) 3, no. 2 (2020): 156167.

Wadi, Husnan. "Perselisihan Keadilan, Kemanfaatan, dan Kepastian Hukum dalam Privatisasi Sumber Daya Air." Jurnal IUS II, no. 5 (2014): 219-238. 